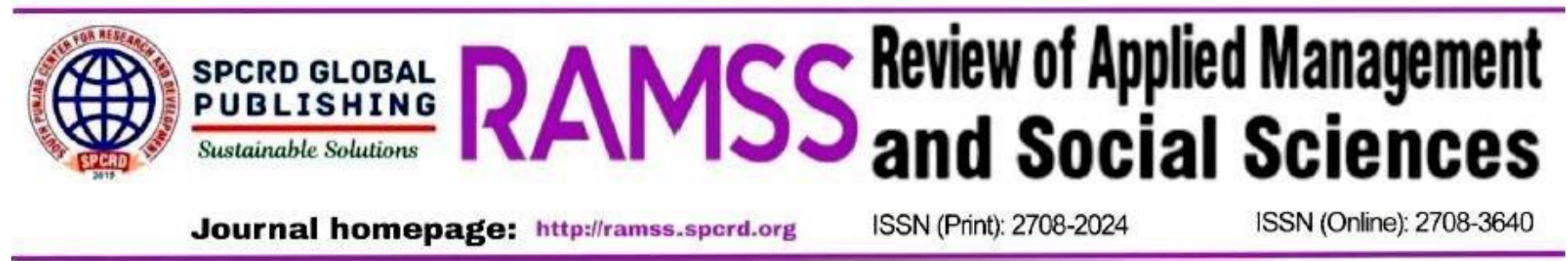

\title{
An Empirical Analysis of the Determinants of Employment Status in District Multan (Pakistan)
}

\section{Muhammad Ramzan Sheikh ${ }^{a}$, Imran Sharif Chaudhry ${ }^{\text {b }}$, Muhammad Hanif Akhtar ${ }^{\text {, }}$ Hammad Ali ${ }^{\mathrm{d}}$}

${ }^{a}$ Associate Professor, School of Economics, Bahauddin Zakariya University, Multan

Email: ramzansheikh@bzu.edu.pk

${ }^{\mathrm{b}}$ Professor, School of Economics, Bahauddin Zakariya University, Multan

Email: imran@bzu.edu.pk

${ }^{\mathrm{c}}$ Professor, Department of Commerce, Bahauddin Zakariya University, Multan

Email: haneefakhtar@bzu.edu.pk

${ }^{\mathrm{d}}$ M.Phil Economics, NCBA\&E Multan

Email: ahammad314@gmail.com

\begin{tabular}{ll}
\hline ARTICLE DETAILS & ABSTRACT \\
\hline History: & $\begin{array}{l}\text { Employment is very cogent macroeconomic factor in economic decision } \\
\text { Accepted } 22 \text { April } 2020\end{array}$ \\
Available Online 15 June 2020 & $\begin{array}{l}\text { employment statuses in their economic life. This study shows a } \\
\text { pragmatic analysis of the factors that determine the employment status }\end{array}$ \\
\hline Keywords: & in district Multan, based on primary data set of 250 respondents \\
Employment Status, Multinomial & collected through stratified sampling. Multiple Logit technique has been \\
Logit model, Multan & applied. The findings of the study have shown that a range of socio- \\
JEL Classification: & economic and demographic factors are responsible to determine the \\
J21, C13 & employment status. The study is also furnished with some relevant \\
& policy implications.
\end{tabular}

DOI: $10.47067 /$ ramss.v3i1.20

(C) 2020 The authors. Published by SPCRD Global Publishing. This is an open access article under the Creative Commons Attribution-

NonCommercial 4.0

Corresponding author's email address: ramzansheikh@bzu.edu.pk

\section{Introduction}

It is well established fact that population is an asset and obstacle simultaneously. The countries that have invested in their human beings are now categorized developed countries and on the contrary the counties that have not given priority to their humans, are now counted in developing nations. Human beings without conversion into human capital may create dependency burden due to illiterate, unqualified, incapable and untrained persons. In other words, population is universal variable which absorbs and enhances the resources. Policy makers consider demographic factors like population pyramid and its composition indispensible for formulating the national development goals and targets. 
The national economic plans are devised while considering employment opportunities, poverty reduction and social safety projects (Pakistan, 2016).

Social welfare maximization is the prime objective of budgetary policy. State is responsible to provide employment opportunities to its masses besides the provision of many social goods and services. Unemployment allowances and compensations are provided in developed countries so that the objective of social welfare might be achieved. However, the countries like Pakistan are in debt trap and vicious circle of poverty, are not in a position to offer its citizens such type of public transfer payments are constrained to draw up such polices (Mincer, 1974; Killings worth and Heckman, 1986).

Employment formation is at cross roads in the South countries like Pakistan. Every government is pursuing important steps to accelerate employment opportunities in the country. Pakistan stands at 9 th position with respect to the labor force and 6th most populous country in the world. This is also worth mentioning that Pakistan possesses unprecedented the most young people in the world that can be an asset if they are provided skills, training and employment opportunities (Pakistan, 2017).

Only employment is not enough to provide a solution. The labor force must be trained and equipped with immediate employment opportunities. Inadequate employment is unacceptable as underemployed workers are treated to be a major incidence of the economy. Conducive working environment is indispensable to improve the productivity of the inputs, otherwise skills and abilities of the workers will remain the same. Professional skills and wages should be on the rise. In Pakistan, employment is identified high levels of illiteracy and low levels of skills. Almost $46 \%$ of the labor force has only one or less than one year of schooling. If there is no skilled, educated and trained manpower, Pakistan will be difficult to compete in a globalized world. There is also a disparity between the needs and supply of educated and deferential labor force (Faridi, 2011).

Government of Pakistan is fully aware of the issue of unemployment. The labor force is currently estimated 61.04 Million out of which employed labor force is 57.42 Million. The unemployment rate is 5.93 percent. Recently, the government of Pakistan has offered many revolutionary schemes by recognizing the importance of youth in the socio-economic development of the country. These schemes are Youth Business Loan Scheme, Provision of Laptops to Talented Students, Interest Free Loan, Youth Skill Development, Youth Training Scheme and Fee Reimbursement Scheme. These schemes are aimed at to enable the youth of country employable as the young people would get higher education, soft and hard skills, information technology, on job training, internships after utilizing these schemes (Pakistan, 2017).

Mostly empirical literature of labor economics focuses on the employment and growth nexus. A little attention has been given to the sort out the decision making of households to determine the factors of their employment status. The labor-leisure choice theory in the form of inter-temporal choice suggests the decision makers to choose labor or leisure based on utility that they may acquire indirectly in the form of income and goods and services or directly from leisure. An idea that can be extracted from the theory is that while one person chooses to work than the leisure hours which sort of job or employment he should choose. This study is a seminal study that identifies the factors of employment status especially in Multan district. There is a need for a comprehensive policy to address the prevailing problems in the labor and employment sectors. This study discusses issues related to the participation of labor in economic activities.

The rest of the paper is structured as: Section 2 explains the concept and definition of 
employment status. Section 3 describes the profile of study area while section 4 describes the review of empirical studies. In section 5, we have discussed the model and data sources. Section 6 explains the methodology. Section 7 presents the discussions on results and finally in section 8 , we have shown conclusions and policy implications.

\section{Employment Status: Concept and Definition}

Standard employment measures include all persons aged 10 and above who have worked for at least one hour during the participation period and are paid "employment" or "self-employed". Persons who are permanently or normally working for any reason during the reference period are also considered to be employed regardless of the absence time whether the worker continues to receive wages during his absence formal workers include those who are 16 years of age or older during the survey week (Labor Force Survey, 2015-2016).

The employment status refers to the type of employment contract with other people or organizations. The status of economically active persons in employment whether he or she is the employer's own account staff, employees or unpaid family workers.

\subsection{Employee}

Work for public or private employers and receive remuneration for wages, salaries, commissions, tricks, fares or in kind. (Labor Force Survey, 2015-16)

Staff divided into

- Regular paid employees with fixed wage.

- Casual paid employment.

- Paid workers are required to work or work.

- Paid non-family apprentice

\subsection{Employer}

Those who work

- Own account

- With one or few partners

- One or more employee engaged on a continuous basis

\subsection{Own account worker}

According to own account worker the person has been

- Own Account

- One or few partners at self-employment job

- Without any employee engaged on a continuous basis

\subsection{Unpaid Family Worker}

A person who works without pay in cash or in kind in economic enterprises

\section{Profile of Study Area}

Punjab has 36 districts and 9 divisions and Multan is a district and located in the Southern Punjab. Multan is the 7th largest city of Punjab having population of 1.87 Million. The area of Multan district is around 3721 sq.km. The boundary of this district is linked with Lodhran, Vehari, Khanewal and M.Garh. According to physical features, the Chanab river is touched from one side and the other side is landlocked. 
Multan city is recognized as city of saints because Sufi's and saints had stayed here for preaching of Islam. Ahmad Shah Abdali and Fareed ud din Ganjshakar was born in Multan. The climate of Multan district is hot. Dust storms are recurrent in the summer especially in May and June. About 60.67\% of population of Multan district is Saraiki speaking, 21.64\% is Punjabi speaking, $15.86 \%$ is Urdu speaking $0.62 \%$ is pashtoo and $0.10 \%$ is Bloch community and rest are others (2017 census of Pakistan). In summer season, maximum temperature of Multan is $46^{\circ} \mathrm{C}$ and minimum temperature is $28^{\circ} \mathrm{C}$. However $21^{\circ} \mathrm{C}$ is the maximum temperature and minimum temperature is $4.5^{\circ} \mathrm{C}$ in the winter. Total population of Multan district is 1.87 million. The population density is 925.4 per square $\mathrm{Km}$. The literacy rate of Multan district is $43.4 \%$. Urban area is more literate than the rural areas. A sample of 250 households has been taken based on information on population size, population, age, rural urban proportions and family characteristics. (Census, 2018)

\section{Review of Empirical Studies}

The review of assorted empirical studies is vital to investigate the any issue under consideration. We have reviewed some important studies that have focused on the factors of employment status. Summary of the studies is displayed in Table 1.

Table 1: Summary of Studies on Employment Status

\begin{tabular}{|c|c|c|c|}
\hline Reference(s) & $\begin{array}{c}\text { Type of } \\
\text { Data }\end{array}$ & Methodology & Main Results \\
\hline $\begin{array}{l}\text { Le } \\
\text { (2000) }\end{array}$ & $\begin{array}{c}\text { Time Series } \\
\text { Data }\end{array}$ & $\begin{array}{lc}\text { Dual } & \text { Cross } \\
\text { sectional } & \text { Model }\end{array}$ & $\begin{array}{l}\text { The study has inferred that capital } \\
\text { educational attainment job characteristics } \\
\text { and marital status are the core factors that } \\
\text { determinant the immigrant self- } \\
\text { employment in Australia. Moreover } \\
\text { common language ethnicity have also } \\
\text { appeared as strong factors of employment } \\
\text { status }\end{array}$ \\
\hline $\begin{array}{l}\text { Pietrobelli, } \\
\text { Rabelotti and } \\
\text { Aquilina } \\
(2004)\end{array}$ & Panel Data & $\begin{array}{l}\text { Ordinary Least } \\
\text { Square Method } \\
\text { (OLS) }\end{array}$ & $\begin{array}{l}\text { This study explores the factors of self- } \\
\text { employment with respect to developing } \\
\text { countries. The findings exhibit that self- } \\
\text { employment is inversely linked with } \\
\text { development. Moreover, it is also pointed } \\
\text { out that manufactured exports in value } \\
\text { added form show entrepreneurship create } \\
\text { self-employment in the countries. }\end{array}$ \\
\hline $\begin{array}{l}\text { Nikolova and } \\
\text { Barger } \\
(2010)\end{array}$ & $\begin{array}{l}\text { Primary } \\
\text { Data } \\
\text { Analysis }\end{array}$ & $\begin{array}{l}\text { Binomial Probit } \\
\text { Model }\end{array}$ & $\begin{array}{l}\text { The findings of the study show that gender } \\
\text { differences along with education and } \\
\text { ethnicity are most influential variable that } \\
\text { determining the self-employment status in } \\
\text { USA }\end{array}$ \\
\hline $\begin{array}{l}\text { Faridi et al. } \\
(2010)\end{array}$ & $\begin{array}{l}\text { Primary } \\
\text { Data } \\
\text { Analysis }\end{array}$ & $\begin{array}{l}\text { Multinomial } \\
\text { Logistic } \\
\text { Regression }\end{array}$ & $\begin{array}{l}\text { The findings of the study show that there } \\
\text { are many factors of employment status in } \\
\text { Bahawalpur district. Educational factor } \\
\text { related to respondent and his relations has }\end{array}$ \\
\hline
\end{tabular}




\begin{tabular}{|c|c|c|c|}
\hline & & & $\begin{array}{l}\text { appeared as cogent factor to determine the } \\
\text { employment status. The study also suggest } \\
\text { development programs in the rural areas } \\
\text { development }\end{array}$ \\
\hline $\begin{array}{l}\text { Faridi et al. } \\
(2010)\end{array}$ & $\begin{array}{l}\text { Primary } \\
\text { Data } \\
\text { Analysis }\end{array}$ & $\begin{array}{l}\text { Multinomial } \\
\text { Logistic } \\
\text { Regression }\end{array}$ & $\begin{array}{l}\text { The study has explored the micro factors } \\
\text { of self-employment in Pakistan. The } \\
\text { findings exhibit that age, experience and } \\
\text { health assets are the significantly and } \\
\text { positively influence the self-employment } \\
\text { status. }\end{array}$ \\
\hline $\begin{array}{l}\text { Senanayaka } \\
\text { and Kumara } \\
\text { (2012) }\end{array}$ & $\begin{array}{l}\text { Primary } \\
\text { data }\end{array}$ & $\begin{array}{l}\text { Multinomial } \\
\text { Logistic } \\
\text { Regression }\end{array}$ & $\begin{array}{l}\text { This study has examined the various } \\
\text { determinants of employment status of } \\
\text { elderly people in Sri Lanka. The results } \\
\text { revealed that half of the Sri Lanka elderly } \\
\text { people are not working. A less percentage } \\
\text { of elderly people in engaged in labor } \\
\text { market. Remittances, bad health condition } \\
\text { and social security benefit are the main } \\
\text { factors that minimize the elderly people to } \\
\text { work in the labor market in Sri Lanka. }\end{array}$ \\
\hline $\begin{array}{l}\text { Dunga and } \\
\text { Sekatane } \\
(2014)\end{array}$ & $\begin{array}{l}\text { Primary } \\
\text { Data } \\
\text { Analysis }\end{array}$ & $\begin{array}{l}\text { Multinomial } \\
\text { Logistic } \\
\text { Regression } \\
\text { Analysis } \\
\end{array}$ & $\begin{array}{l}\text { The study has inferred that age, education } \\
\text { and government grants are the main } \\
\text { factors to choose the employment status. }\end{array}$ \\
\hline $\begin{array}{l}\text { Kaur } \\
(2016)\end{array}$ & $\begin{array}{l}\text { Primary } \\
\text { Data } \\
\text { Analysis }\end{array}$ & $\begin{array}{l}\text { Ordinary Least } \\
\text { Square method }\end{array}$ & $\begin{array}{l}\text { This study examined that in addition to } \\
\text { Assam, the number of women's } \\
\text { participation in other North-Eastern India } \\
\text { countries has increased, and this ratio is } \\
\text { more than the national level. }\end{array}$ \\
\hline $\begin{array}{l}\text { Tripathi } \\
\text { (2016) }\end{array}$ & $\begin{array}{l}\text { Primary } \\
\text { Data } \\
\text { Analysis }\end{array}$ & $\begin{array}{l}\text { Multinomial } \\
\text { Logit Model }\end{array}$ & $\begin{array}{l}\text { The finding of the study point out that } \\
\text { education land belonging are main factors } \\
\text { that determine the employment and } \\
\text { unemployment in north east state of India. } \\
\text { People with more education and land } \\
\text { holdings are more inclined towards self- } \\
\text { employment. }\end{array}$ \\
\hline
\end{tabular}

Source: Authors' compilation

In a nutshell, we can point out that there are some useful studies that focus on determination of employment statues. Mostly studies are focusing on the determinants of self-employment and ignore the determinants of employment status in aggregate. This study discovers the socioeconomic and demographic factors of various employment statuses in Multan district which has not been investigated in the labor economics literature according to best of our knowledge.

\section{Model Specification and Data}

To delve into the determinants of employment status in Multan district, following model can be suggested: The functional form of employment status model is: 
In econometric form, the model can be written as:

$$
\begin{aligned}
& E M P=\beta_{0}+\beta_{1} E D U R+\beta_{2} E D U S+\beta_{3} E D U F+\beta_{4} A G E R+\beta_{5} I N C O M+\beta_{6} M A R S+\beta_{7} S E X+\beta_{8} F S \\
& +\beta_{9} H S I Z E+\beta_{10} M A R S * E D U R+\varepsilon
\end{aligned}
$$

The description of variables is summarized in Table 2.

\begin{tabular}{|c|c|c|}
\hline Variables & Abbreviation & Description of Variables \\
\hline \multicolumn{3}{|c|}{ Dependent Variable } \\
\hline Employment & EMP & $\begin{array}{l}=1 \text { means Employee } \\
=2 \text { means Employer } \\
=3 \text { means Own Account Worker }\end{array}$ \\
\hline \multicolumn{3}{|c|}{ Independent Variables } \\
\hline $\begin{array}{l}\text { Education } \\
\text { Respondent }\end{array}$ & EDUR & $\begin{array}{l}\text { It is measured in the years spent in education till } \\
\text { last degree attained by the respondent }\end{array}$ \\
\hline $\begin{array}{l}\text { Education } \\
\text { Spouse }\end{array}$ & EDUS & $\begin{array}{l}\text { It is measured in the years spent in education till } \\
\text { last degree attained by the spouse of the } \\
\text { respondent }\end{array}$ \\
\hline $\begin{array}{l}\text { Father's } \\
\text { education }\end{array}$ & FEDU & $\begin{array}{l}\text { It is measured in the years spent in education till } \\
\text { last degree attained by the father of the } \\
\text { respondent }\end{array}$ \\
\hline Age Respondent & AGER & Age of the respondent in years \\
\hline Income & INCOM & $\begin{array}{l}\text { The family income of the respondent measured } \\
\text { in thousand per month received. }\end{array}$ \\
\hline Marital status & MARS & $\begin{array}{l}=1 \text { if respondent is married } \\
=0 \text { if respondent is unmarried }\end{array}$ \\
\hline Sex & SEX & $\begin{array}{l}=1 \text { if respondent is male } \\
=0 \text { if respondent is female }\end{array}$ \\
\hline Family size & FAMS & $\begin{array}{l}=1 \text { if respondent lives in nuclear family } \\
=0 \text { if respondent lives in joint family }\end{array}$ \\
\hline Household Size & HSIZE & Size of the household or total family members \\
\hline $\begin{array}{l}\text { Interaction } \\
\text { Term }\end{array}$ & MARS*EDUR & $\begin{array}{l}\text { Interaction Term of Martial status and education } \\
\text { of respondent }\end{array}$ \\
\hline
\end{tabular}

\section{Table 2: Variables and its Description}

\section{Methodology: Logistic Regression}

We have applied Logistic Regression to determine the impact of specific family or individual characteristics of employment status. In econometrics, we have used a multivariate analysis. We used a general function.

$$
Y_{i}=f\left(X_{i}\right) i=(1,2,3 \ldots \ldots . . \mathrm{n})
$$

Where: 
Y $i=$ Employment Status

$\mathrm{X} i=$ Different socio-economic variables

Logistic regression is a multiple regression in which the dependent variable is categorical variable1 while the explanatory variables are categorical or continuous variable. It has two kinds: (i) Binary Logistic Regression (BLR) and (ii) Multinomial Logistic Regression (MLR). In binary logistic regression, the outcome variable consists of two categories only but in multinomial logistic regression, the dependent variable has more than two categories. Multinomial logistic regression is also known as polychotomous regression. To start with the simplest form of the logistic regression, we first discuss the binary logistic regression and then extend it to multinomial logistic regression and then extend it to multinomial logistic regression. In simple linear regression the dependent variable ' $\mathrm{Y}$ ' can be predicted from the equation (4).

$$
Y_{i}=\alpha_{0}+\alpha_{1} X_{1 i}+\varepsilon_{i}
$$

Where:

$\mathrm{Yi}=$ outcome variable

$\alpha_{0}=$ Intercept

$\alpha_{0}=$ Slope of the straight line

$\mathrm{Xi}=$ Predictor variable

$\varepsilon_{i}=$ Residual term

We estimate the above equation to minimize the squared distance between the observed and predicted values of the outcome variables (OLS). In multiple regressions, there are many explanatory variables that can be shown by equation 5 .

$$
Y_{i}=\alpha_{0}+\alpha_{1} X_{1 i}+\alpha_{2} X_{2 i}+\ldots \ldots \ldots \ldots+\alpha_{n} X_{n i}+\varepsilon_{i}
$$

In this equation $\alpha_{\mathrm{s}}$ are the regression coefficients of the respective variable X.

In contrast to OLS where we predict the value of outcome variable Y given the known values of $\mathrm{X}_{1}$, logistic regression predicts the probability of outcome variable ' $\mathrm{Y}$ ' given the values of $\mathrm{X}_{1}$. There are many similarities between the logistic regression and simple linear and multiple regression. If there is only one explanatory variable $\mathrm{X}_{1}$, we can predict the probability of $\mathrm{Y}$ in the logistic regression equation as:

$$
P(Y)=\frac{1}{1+e^{-\left(\alpha_{0}+\alpha_{1} X_{1 i}\right)}}
$$

Where:

$\mathrm{P}(\mathrm{Y})$ = Probability of occurrence of $\mathrm{Y}$

$e=$ Base of natural Logarithm

Note that the expression in the bracket is same to the equation (4). In analogous to these linear regressions, we can extend the equation (4) by adding different predictors and after doing this process.

1 Categorical variable can be called qualitative or discrete variables. We can classify the categorical variables into nominal, dichotomous and ordinal variables. In nominal variables, the variables have two or more than two categories but their intrinsic order does not matter while in ordinal variables, intrinsic order matters: so far dichotomous variables are concerned, these are also nominal variables having two categories or levels 
The equation can be expressed as:

$$
P(Y)=\frac{1}{1+e^{-\left(\alpha_{0}+\alpha_{1} X_{1 i}+\alpha_{2} X_{2 i}+\ldots \ldots \ldots .++\alpha_{n} X_{n i}\right)}}
$$

This equation is similar to the equation (5) except the number of the predictor has been increased. In a nutshell, we can infer that one predictor version of logistic regression encapsulates the simple linear regression and multiple predictor version of logistic regression encompasses the multiple regression equation.

Even there are many resemblances between the logistic regression and linear regression but we are unable to apply linear regression of the outcome variable is categorical.

In logistic regression as the outcome variable is categorical. So, the assumption of linearity does not hold. So, we can transform the non-linear relationship into linear form by taking the logarithm of the equation. 2

\section{Results and Discussions}

This section explains the determinants of employment status in Multan district. The study is based on cross section data of 250 respondents having the assorted employment status. Multinomial logistic regression has been applied to investigate the correlates of employment status. Table 2 shows the results of step summary3. Two models have been examined i.e. Model o (main effects model) and Model 1(Model with interaction term). The table shows the overall significance of the model. The values of model fitting criteria i.e. AIC and BIC are smaller after the introduction of interaction term in the model 1.

Table 3: Step Summary Results

\begin{tabular}{|c|c|c|c|c|c|c|c|}
\hline \multirow[b]{2}{*}{ Model } & \multirow[b]{2}{*}{ Effect(s) } & \multicolumn{3}{|c|}{ Model Fitting Criteria } & \multicolumn{3}{|c|}{ Effect Selection Tests } \\
\hline & & AIC & BIC & $\begin{array}{c}\text {-2 Log } \\
\text { Likelihoo } \\
\text { d }\end{array}$ & $\begin{array}{c}\text { Chi- } \\
\text { Square }\end{array}$ & $\begin{array}{l}\text { D } \\
\text { f }\end{array}$ & Sig. \\
\hline $\mathrm{O}$ & $\begin{array}{c}\text { Intercept, } \\
\text { EDUR,EDUS, } \\
\text { EDUF, } \\
\text { AGER, } \\
\text { INCOM, } \\
\text { MARS, SEX, } \\
\text { FS, HSIZE }\end{array}$ & $\begin{array}{c}369.69 \\
8\end{array}$ & 440.047 & 329.698 & • & & \\
\hline
\end{tabular}

2 The multiple logistic regressions show the multiple linear regression equation in logarithm form (logit) and hence the problem of violation of linearity the parameters of logistic regressions can be obtained by applying the maximum likelihood method.

3 It is called step summary results due to the fact that this table explains the different models are entered in steps. Normally this table is not reported in the empirical studies but it shouldn't be ignored as it shows the stepwise analysis of different models. 


\begin{tabular}{|c|c|c|c|c|c|c|c|}
1 & $\begin{array}{c}\text { MARS * } \\
\text { EDUR }\end{array}$ & 359.46 & 436.849 & 315.465 & 14.233 & 2 & 0.001 \\
\hline
\end{tabular}

Stepwise Method: Forward Entry

The value of AIC decreases from 369.69 to 359.46 and similarly the value of BIC also decline from 440.04 to 436.84 . This indicates that the model with interaction term is better fit than just main effect based model. The chi-square value 4 is also significant in this model.

Table 4 exhibits the statistics of the final model which replicates the model fitting criterion from the last line of Table 3. This table is also founded on the likelihood ratio test. The -2log likelihood5 ratio test indicates that either the independent variable has bearing on dependent variable. In fact log likelihood encapsulates the degree of unexplained variability and the change or difference in log likelihood shows the extent of new variance in the model.

Table 4: Model Fitting Information Results

\begin{tabular}{|c|c|c|c|c|c|c|}
\hline \multirow{2}{*}{ Model } & \multicolumn{3}{|c|}{ Model Fitting Criteria } & \multicolumn{3}{c|}{$\begin{array}{c}\text { Likelihood Ratio } \\
\text { Tests }\end{array}$} \\
\cline { 2 - 7 } & AIC & BIC & $\begin{array}{c}\text {-2 Log } \\
\text { Likelihoo } \\
\text { d }\end{array}$ & $\begin{array}{c}\text { Chi- } \\
\text { Squar } \\
\text { e }\end{array}$ & df & Sig. \\
\hline $\begin{array}{c}\text { Interce } \\
\text { pt Only }\end{array}$ & $\begin{array}{c}487.39 \\
1\end{array}$ & $\begin{array}{c}494.42 \\
6\end{array}$ & 483.391 & & & \\
\hline Final & $\begin{array}{c}359.46 \\
5\end{array}$ & $\begin{array}{c}436.84 \\
9\end{array}$ & 315.465 & $\begin{array}{c}167.92 \\
6\end{array}$ & 20 & 0 \\
\hline
\end{tabular}

Source: Author's calculations

The results of Table 4 show that the value of chi-square test has decreased in the unexplained variance from the base line model (483.39) to the final model (315.46). The difference between these two is 167.92 i.e. significant and we can infer that our final model shows the significant amount of original variability.

Table 5 portrays the results of goodness of fit of the model. Two tests i.e. Pearson test and Deviance test have been estimated to show the goodness of fit. If the chi-square values of these tests are insignificant as in our case, it means that the predicted values of the model are not different from the observed values.

Table 5: Goodness-of-Fit Results

\begin{tabular}{|c|c|c|c|}
\hline & $\begin{array}{c}\text { Chi- }^{-} \\
\text {Square }\end{array}$ & Df & Sig. \\
\hline Pearson & 310.09 & 394 & 0.999 \\
\hline
\end{tabular}

4The chi-square for entry is based on the likelihood ratio test.

5 Likelihood means probability. -2log likelihood $=-2 L L_{i, j}=-2 \ln \left(\operatorname{Pr}_{i, j}\right)$. In this test, following steps are involved: Firstly, the model is estimated without considering the independent variables and secondly, the model is estimated by considering the independent variables and thirdly the second model is deducted from the first. This test follows the chi square distribution that is used to determine the significance. If the two models yield the same results and their difference is zero, it shows the insignificant results. If the two models yield the different results and their difference is greater than or less than zero, it shows the significant results. 


\begin{tabular}{|c|c|c|c|} 
Devianc & 307.82 & 394 & 1 \\
$\mathrm{e}$ & 7 & 394 & \\
\hline
\end{tabular}

Source: Author's calculations

In other words the model is good fit. The probability values of both the model is greater than 0.05 (Pearson=0.99 and Deviance=1) indicating that both the statistics have no contrasting results. Table 6 shows the results Pseudo R-square based on three statistics test namely Cox and Snell test, Nagelkerke test and McFadden test having the values $0.49,0.56$ and 0.34 respectively. The results of first two tests are almost similar but the value of McFadden test is a little bit low. Therefore, we can say that our model has decent-size effects.

\section{Table 6: Pseudo R-Square Results}

\begin{tabular}{|l|c|}
\hline Cox and Snell & 0.491 \\
\hline Nagelkerke & 0.569 \\
\hline McFadden & 0.341 \\
\hline
\end{tabular}

Source: Author's calculations

Table 7 demonstrates the likelihood ratio test for the independent variables in the model. These ratios are used to determine the significance of the independent variables. The chi-square values of all the explanatory variables along with their respective probabilities show the significant main effect on the employment status except the joint family system and household size6.

Table 7: Likelihood Ratio Tests Results

\begin{tabular}{|l|c|c|c|c|c|c|}
\hline \multirow{2}{*}{ Effect } & \multicolumn{3}{|c|}{ Model Fitting Criteria } & \multicolumn{2}{c|}{ Likelihood Ratio Tests } \\
\cline { 2 - 7 } & $\begin{array}{c}\text { AIC of } \\
\text { Reduced } \\
\text { Model }\end{array}$ & $\begin{array}{c}\text { BIC of } \\
\text { Reduced } \\
\text { Model } \\
\text { Likelihoo } \\
\text { d of } \\
\text { Reduced } \\
\text { Model }\end{array}$ & $\begin{array}{c}\text { Chi- } \\
\text { Square }\end{array}$ & df & Sig. \\
\hline $\begin{array}{l}\text { Intercep } \\
\text { t }\end{array}$ & 359.465 & 436.849 & $3.155^{\mathrm{E} 2}{ }^{\mathrm{a}}$ & 0.00 & 0 & - \\
\hline EDUR & 359.465 & 436.849 & $3.155^{\mathrm{E} 2}$ & 0.00 & 0 & -- \\
\hline EDUS & 379.55 & 449.899 & 339.55 & 24.085 & 2 & 0.000 \\
\hline EDUF & 385.715 & 456.064 & 345.715 & 30.25 & 2 & 0.000 \\
\hline AGER & 367.999 & 438.348 & 327.999 & 12.534 & 2 & 0.002 \\
\hline INCOM & 360.651 & 431 & 320.651 & 5.185 & 2 & 0.075 \\
\hline MARS & 369.705 & 440.054 & 329.705 & 14.24 & 2 & 0.001 \\
\hline SEX & 420.936 & 491.285 & 380.936 & 65.471 & 2 & 0.000 \\
\hline FS & 357.164 & 427.513 & 317.164 & 1.699 & 2 & 0.428 \\
\hline HSIZE & 356.295 & 426.644 & 316.295 & 0.83 & 2 & 0.660 \\
\hline $\begin{array}{l}\text { MARS * } \\
\text { EDUR }\end{array}$ & 369.698 & 440.047 & 329.698 & 14.233 & 2 & 0.001 \\
\hline
\end{tabular}

6By default there is no result on respondent education because when chi-square value is zero then the probability of that has no results. 
Source: Author's calculations

Note: The chi-square statistic is the difference in -2 log-likelihoods between the final model and reduced model. The reduced model is formed by omitting an effect from the final model. The null hypothesis is that all parameters of that effect are 0 .

a. This reduced model is equivalent to the final model because omitting the effect does not increase the degrees of freedom

These likelihood ratios explain that which independent variables significantly predict the outcome variable of employment status. This however, does not specify the direction of impact exactly. For this, we have to utilize Multiple Logistic Regression to explore the exact impact of individual parameters on the development variable.

These likelihood ratios explain that which independent variables significantly predict the outcome variable of employment status. This however, does not specify the direction of impact exactly. For this, we have to utilize Multiple Logistic Regression to explore the exact impact of individual parameters on the development variable.

In Table 8, we have shown the Multinomial Logistic Regression7 estimates of the determinants of employment status in Multan district. The dependent variable is employment status which is categorical variable having three categories i.e. Employee, Employer and Own account worker. The reference category is employee. This table is comprised of two sections: first section explains the determinants of 'employer' employment status in comparison with 'employee' employment status and the other section indicates the determinants of 'own account worker' employment status in comparison with the reference category of 'employee'.

Firstly we explain the determinants of 'employer' employment status. The predictor variables are EDUR, EDUS, EDUF, AGER, INCOM, HSIZE, MARS (two level categorical variable), Sex (two level categorical variable), FS (two level categorical variable) and interaction term is (MARS*EDUR). $\beta_{\mathrm{s}}$ are the multinomial logistic regression 8 coefficients which are estimated through maximum likelihood method. These show how the log odds units of the outcome variables. Exp $(\beta)$ is the exponenting regression coefficient. These are also known as odds ratio or relative risk ratiog.

Now we explain the $\beta$ and $\operatorname{Exp}(\beta)$ values. The first determinant is education of the respondent (EDUR), its value is 0.46 which is positive and highly significant having probability of 0.01. It means that per one year increase in the education of the respondent, the log odds of the employer in comparison with the employee also increase by 0.46 units. If we explain the $\operatorname{Exp}(\beta) 10$ of this variable it shows the relative risk ratio for a one year increase of the respondent education is 1.58 for being employer versus employee. The possible reason of this positive association between the respondent's

7 Probability means chances of occurrence and it remains between o and 1. Odds mean the ratio between probability of occurrence and probability of not occurrence and for odds it is not necessary that its value remains between 0 and 1. Odds are also called relative risk. If we take the log of odds, it becomes Logit.

8Multiple nominal logistic model is (k-1) based model meaning that the dependent variable is comprised of $k$ outcomes and (k-1) means one outcome which is known as reference category is subtracted.

9Odds ratio means that the ratio between risk of outcome falling in comparison group to the risk of outcome falling in the reference group.

10If the odds ratio is greater than 1 , it means that the risk of outcome falling in the comparison group is more than the risk of outcome falling in the reference group so the chances of comparison outcome is more to prevail. 
education and log odds of the 'employer' employment status is that if a person is more educated, he would be more enthusiastic to set up his own business rather than to become an 'employee'. As an educated person, he learns entrepreneurship and leadership qualities so he is more inclined towards starting up his own business and become an 'employer' rather than 'employee'. Our results are in line with the study (Blau and Khan, 2005).

Now we come to the education of the closed relatives i.e., spouse education and father education. First we explain the impact of spouse education in the determination of employer versus employee status of the respondent. The coefficient of the multinomial regression of spouse education $(\beta)$ has interestingly appeared with -ive sign implying that a one year upsurge in the spouse education will decrease the log odds of being employer than the employee. It is statistically highly significant as well. If we explain this variable in terms of odds ratio $\operatorname{Exp}(\beta)$, it is less than one illuminating that the reference group is more likely to prevail than the comparison group. There may be many explanations of this negative connection. Firstly, the females in the South Punjab11 are normally risk averter and conservative in nature and they do not believe in entrepreneurship. See for example (Ohlsson, Broome and Bevelander, 2010 and Senanayaka and Kumara, 2012).

Thus even after getting the education they want a secured job of her spouse in the form of employee rather than employer. Secondly, if her husband is employee, she would get a fixed income rather than the random walks in income. Thirdly, the educated woman knows that if her husband would be an employer in a company, he has to spend most time to promote and flourish his own business rather than as an employee in an entity. So she prefers her husband in the employee status rather than employer. Our results are compatible with (Saikia and Mazumder, 2015 and Blau and Khan, 2005)

Father education is positive and statistically highly significant. The coefficient of father education in the form of $\beta$ is 0.95 . It means that the relative log odds of employer increase in comparison with the employer as the father's education increases by one year. The exponential regression coefficient $\operatorname{Exp}(\beta)$ or odds ratio of this variable is 2.60 indicating the relative risk ratio for one year increase in father's education is 2.60 for being in employer versus employee.

11 Multan is situated in the South Punjab. It is less developed area in comparison of the North Punjab. The people are poor and less educated here. 
Table 8: MLR Estimates of Employment Status in Multan

\begin{tabular}{|c|c|c|c|c|c|c|c|c|}
\hline \multirow{3}{*}{$\begin{array}{l}\text { Explanatory } \\
\text { Variables }\end{array}$} & \multirow[t]{2}{*}{ B } & \multirow{2}{*}{$\begin{array}{l}\text { Std. } \\
\text { Error }\end{array}$} & \multirow[t]{2}{*}{ Wald } & \multirow[t]{2}{*}{ Df } & \multirow[t]{2}{*}{ Sig. } & \multirow[t]{2}{*}{$\operatorname{Exp}(B)$} & \multicolumn{2}{|c|}{$\begin{array}{l}95 \% \text { Confidence } \\
\text { Interval for } \\
\operatorname{Exp}(B) \\
\end{array}$} \\
\hline & & & & & & & $\begin{array}{l}\text { Lower } \\
\text { Bound }\end{array}$ & $\begin{array}{l}\text { Upper } \\
\text { Bound }\end{array}$ \\
\hline & \multicolumn{8}{|c|}{ Employer vs. Employee } \\
\hline Intercept & 10.375 & $5 \cdot 313$ & 3.814 & 1 & 0.051 & --- & --- & --- \\
\hline EDUR & 0.461 & 0.18 & 6.593 & 1 & 0.01 & 1.586 & 1.115 & 2.256 \\
\hline EDUS & -1.105 & 0.271 & 16.58 & 1 & 0.00 & 0.331 & 0.194 & 0.564 \\
\hline EDUF & 0.958 & 0.239 & 16.02 & 1 & 0.00 & 2.607 & 1.631 & 4.168 \\
\hline AGER & -0.599 & 0.192 & 9.685 & 1 & $\begin{array}{c}0.00 \\
2\end{array}$ & 0.549 & 0.377 & 0.801 \\
\hline INCOM & -2.414 & 1.314 & $3 \cdot 375$ & 1 & $\begin{array}{c}0.06 \\
6\end{array}$ & 0.089 & 0.007 & 1.175 \\
\hline MARS & -58.022 & 3.659 & 251.395 & 1 & $\begin{array}{c}0.00 \\
0\end{array}$ & 0.000 & 0.000 & 0.000 \\
\hline SEX & -4.433 & 1.297 & 11.691 & 1 & $\begin{array}{c}0.00 \\
1\end{array}$ & 0.012 & 0.001 & 0.151 \\
\hline FS & 1.046 & 0.91 & 1.323 & 1 & 0.25 & 2.847 & 0.479 & 16.934 \\
\hline HSIZE & 0.065 & 0.08 & 0.672 & 1 & 0.412 & 1.067 & 0.913 & 1.247 \\
\hline MARS*EDUR & 18.7 & 1.064 & 308.76 & 1 & 0.00 & 1.32 & 1.64 & 1.06 \\
\hline \multicolumn{9}{|c|}{ Own Account Worker vs. Employee } \\
\hline Intercept & -6.761 & 4.948 & 1.867 & 1 & 0.172 & -- & --- & --- \\
\hline EDUR & 0.521 & 0.223 & 5.454 & 1 & 0.02 & 1.684 & 1.087 & 2.607 \\
\hline EDUS & -0.136 & 0.172 & 0.629 & 1 & $\begin{array}{c}0.42 \\
8\end{array}$ & 0.872 & 0.623 & 1.222 \\
\hline EDUF & -0.44 & 0.272 & 2.619 & 1 & $\begin{array}{c}0.10 \\
6\end{array}$ & 0.644 & 0.378 & 1.097 \\
\hline AGER & -0.448 & 0.265 & 2.854 & 1 & $\begin{array}{c}0.09 \\
1\end{array}$ & 0.639 & 0.38 & 1.074 \\
\hline INCOM & 1.15 & 1.244 & 0.855 & 1 & $\begin{array}{c}0.35 \\
5 \\
\end{array}$ & 3.158 & 0.276 & 36.131 \\
\hline MARS & $-55 \cdot 552$ & 1.06 & 2745 & 1 & $\begin{array}{c}0.00 \\
0\end{array}$ & 0.000 & 0.000 & 0.000 \\
\hline SEX & 2.357 & 0.486 & 23.535 & 1 & $\begin{array}{c}0.00 \\
0\end{array}$ & 10.556 & 4.074 & $27 \cdot 352$ \\
\hline FS & -0.159 & 0.809 & 0.039 & 1 & $\begin{array}{c}0.84 \\
4 \\
\end{array}$ & 0.853 & 0.175 & 4.16 \\
\hline HSIZE & -0.013 & 0.08 & 0.026 & 1 & $\begin{array}{c}0.87 \\
2 \\
\end{array}$ & 0.987 & 0.844 & 1.154 \\
\hline MARS*EDUR & 18.166 & 0.000 & --- & 1 & --- & $7 \cdot 75$ & 7.75 & $7 \cdot 75$ \\
\hline
\end{tabular}

Source: Author's calculations

Note: The reference category for Employment status is Employee, for Sex, male is reference category, for FS, family setup is reference category and for MARS, married is reference category. 
The possible reason of positive association between the father's education and 'employer' status of the respondent may be justified on the following grounds. In fact, it is an established fact that the more educated father has more vision and exposure than the low educated fathers. An educated father normally works as an employee than an employer. He knows the pitfalls of being employee in an organization so it is expected that an educated father would convince and encourage his kids to be 'employer' rather than 'employee'. Following studies support our findings for example (Blau and Khan, 2005).

Now we turn to the demographic variable of age. It comes out with the negative sign and is statistically highly significant. The value of age coefficient in the form of $\beta$ is -0.59 indicating that a one year increase in the age of the respondent decreases the log odds of 'employer' in comparison of 'employee' by 0.59 units. The exponential regression coefficient of the same variable shows the prevalence of the reference category. The relative risk ratio for one year increases in the age of the respondent is 0.54 for being in 'employee' than the 'employer'. The possible reason of negative bearing of age of the respondent on 'employer' status can be explained with following reasons. As the age of a person increases, he or she feels fear of not getting the job due to the age restrictions in labor market. So, as the age upturns, he or she is more predisposed to become an 'employee' than the 'employer'. With an increase in age, physical and mental conditions of the person deteriorate and there is less likely that he or she would set up his/her own business and work as an 'employer' than the 'employee'. Moreover, with an increase in age, the person has to face dependents and other social issues. So, he/she is compelled to do a job and work as an 'employee' rather than 'employer'. In Pakistan and particularly in Multan, the people are poor and mostly engaged in agriculture related professions and their per capita income is very low. A person in such circumstances works as an employee than the 'employer' as the age increases. Our results are well-matched with Glick and Shan, 2005; Sen, 2000; Doltan and Makepeace,1987.

The economic variable of income has appeared with negative sign. The $\beta$ coefficient is -2.41 and it is highly significant. It demonstrates that the relative log odds of being 'employer' in comparison with reference category of 'employee' decrease as the size of income increases. In other words, the odds ratio is less than 1 i.e., o.089 suggesting that the relative risk ratio for a one rupee increase in income is o.o89 for being 'employee' rather than 'employer'. This shows that as the income increases, people would go more towards 'employee' status than the 'employer' status. The effect of income on various employment statuses is vague. It can go in either direction. Normally, when people have more income and resources, they would be more inclined to setup their own business and to become an 'employer' rather than the 'employee' but in our case, the reverse is true. The possible reason of this contrasting result may be that our sample is based on Multan district which is considered a less developed region of the country having low income in comparison with the other parts of the country particularly the North Punjab. So, if the income level increases, it cannot be increased to a threshold level that is maintained in other parts of the country. So, the people would not prefer to setup their own business in comparison with 'employee'. As 'employee', people can get a fixed income without any risk and they can get fringe benefits of being 'employee' in the form of pension, gratuity, medical allowances, life insurance etc. Our results are similar to (Doltan and Makepeace, 1987).

Marital status is again a demographic factor which can affect the adoption of different employment status. The sign of marital status is -ive and it is statistically highly significant. The value of marital status coefficient in the form of $\beta$ is $\mathbf{- 5 8 . 0 2 2}$ showing that if a person is unmarried, the log odds of the employer is comparison of employee decreases by 58.022 unit. The exponential regression coefficient of marital status demonstrates the dominance of the reference group. In other words, 
relative risk ratio of adopting the employee status is higher than the employer category. The rationale of this relationship may be corroborated on the following basis. If a person is unmarried, normally in our societies he/she is dependent on other family members but once he/she is going to be married or married, he/she is supposed to be the breadwinner. Moreover, the person does not have so much financial resources for setting up his or her own business so he/she is more inclined towards getting the employee status in the labor market rather than employer. Our results are validated by the following studies Blau and Khan, 2005; Glick and Shan, 2005; Sen, 2000 and Doltan and Makepeace, 1987.

The variable of sex is decomposed into male and female. It can have some bearing on employment status positively or negatively. If the females or males are educated, they have the tendency towards employer status rather than employee otherwise the converse is true. The value of sex is -ive and highly significant. The value of $\beta$ is -4.43 suggesting that if a person is female, the log odds of being employer decreases by 4.43 units. The exponential coefficient regression of the same variable exhibits the prevalence of reference category. The relative risk ratio of being employee is more than the employer. In our case the variable of sex is negative which shows that females would adopt the employee status rather than employer because females are risk averter and dependent in nature in one society so they can never adopt the employer status.

The next variable is family setup. It is social variable showing that the family can be nuclear or joint. The coefficient of family setup is positive suggesting that if the family setup is nuclear based; the people adopt employer status rather than employee. The value of $\beta$ is 1.046 indicating that if the family setup is nuclear based the log odds of being 'employer' relative to the 'employee' increases by 1.046 units. The $\operatorname{Exp}(\beta)$ of the family setup is 2.84 which is greater than 1 showing the prevalence of comparison group. We can justify this result by the argument that is a person lives in nuclear family system; his or her expenditures of living may be low in comparison with the joint family system where they have to feed more people. So in nuclear family system, a person may adopt the status of employer by setting up their own business due to more financial space.

Another demographic factor that can affect the different status of employment adoption is household size. Household size may influence the employment status both positively and negatively. This variable shows the dependency burden in a family because from the number of the person, one can judge the composition and size of the population of the specific household. Normally, as the household size increases with less dependent people, they have more tendencies to become an employer rather than employee because they need not to feed the people and they have more resources to initiate their own business and become employer. In our case, this variable has appeared with positive sign but it is statistically insignificant. The value of household size in the form of $\beta$ is 0.065 exhibiting that a one person increase in household size would increase the log odds of the employer relative to the employee by 0.065 units. The exponential regression coefficient $\operatorname{Exp}(\beta)$ of household size is greater than one which indicates the relative risk ratio for a one person increase in household size is 1.067 for being 'employer' versus 'employee'. The possible reason of positive relationship between household size and log odds of the employer is that as the household size increases, people have the tendency to become an employer due to having more financial resources to setup their own business. Moreover, they have their own workforce to work in the own business. Our results are validated by the following studies (Glick and Shan, 2005; Sen, 2000; Doltan and Makepeace 1987).

Finally we have also included an interaction term of marital status and education of respondent to explore the employment status if the respondent is married and educated. The coefficient of 
education respondent shows the partial effect of education of the respondent on the employment status which is positive and coefficient of marital status (in case of unmarried) is negative on the employment status while the interaction of these two term i.e. EDU and MARS is positive and it shows that the partial effects of respondent education on the employment status of the 'employer' at the mean value of marital status is 18.7. It means that if a person on average remains unmarried and his or her education level increase, he would adopt the employment status of 'employer'12. Similarly it can also be explained if we take the partial effect of marital status on employment status at the mean value of education of the respondent13. It is positive meaning that if a person with mean value of education the impact of marital status on employment status is positive in case of 'employer' status. The possible reason of this positive association of the interaction term is that an unmarried educated person his more optimistic, pragmatic and idealistic view than the married and uneducated so he would obviously choose to be an 'employer' than the 'employee' status.

Now we explain the lower half of Table 8 in which the comparison group is 'own account worker' and reference category is again 'employee'. Now we explain the determinants of employment status in case of 'own account worker' and 'employee'. The first determinant was respondents' education (EDUR), which was 0.521 , with a probability of 0.02 , positive and highly significant. This means that every year the interviewer's education increases, compared with the employee, the employer's logarithm may also increase by 0.521 units. If we explain $\operatorname{Exp}(\beta)$ for this variable, it shows that the relative risk ratio for the year between the account staff and the employee is 1.68. The possible reason for the positive correlation between the degree of education of the interviewee and the employment status of the "self-employed" employment situation is that if a person is highly educated, he will set up his own business more closely rather than becoming an employee As a well-educated person, he learns entrepreneurial spirit and leadership qualities, so he is more inclined to start a business and become "his own account" than "employee". Our results are in line with the studies (Blau and Khan, 2005; Glick and Shan, 2005 and Sen, 2000).

Now we come to the education of closed relatives, that is, spouse education and parental education. First, we explain the impact of spousal education in determining the identity of the account staff and the defendant's employees. The coefficient of multiple regression of spouse education $(\beta)$ It is interesting to note that the increase in spouse education by one year will reduce the logarithmic probability of the employer, not the employee, statistically also very important. If we use this advantage to explain this variable with $\operatorname{Exp}(\beta)$, it is more likely that the variable is less than 1 than the reference group. There may be many reasons for this negative relationship. First of all, women in the Punjab are usually more risky and more conservative, and they do not believe in entrepreneurial spirit. See for example, Glick and Shan, 2005; Sen, 2000; Doltan and Makepeace, 1987).

Thus, even after receiving education, they also want to work safely in the form of an employee rather than an employer's spouse. Secondly, if the husband is an employee, she will receive a fixed income, not a random income. Thirdly, educated women know that if her husband is the employer of the company, he must spend most of his time promoting and developing his own business, not as an entity employee. So she prefers her husband's employee status rather than the employer. Our results are compatible with (Faridi, 2011).

$$
\begin{aligned}
& 12 \frac{\partial E M P}{\partial E D U}=\beta_{1}+\beta_{10} M A R S \\
& 13 \frac{\partial E M P}{\partial M A R S}=\beta_{6}+\beta_{10} E D U R
\end{aligned}
$$


The coefficient of education of father coefficient is -ive and insignificant. The coefficient of parental education form $\beta$ is -0.44 . This shows that as the father's education rises for one year, the relative proportion of the employer relative to the employer increases. The exponential regression coefficient $\operatorname{Exp}(\beta)$ or odds ratio of the variable is 0.64 , indicating that the relative risk ratio for the oneyear increase in parental education is 0.64 .

Now let's look at the age of the population variable. It appears a negative sign, statistically significant. The age coefficient of the $\beta$ form is -0.44 , indicating that the age of the respondent is increased by one year, and the proportion of "employees" in the "unit" is reduced by 0.44 units. The exponential regression coefficients for the same variable show the prevalence of the reference category. The relative risk ratio of the age of the respondent is "employee" is 0.639, not "self-employed". The possible reasons for the negative impact of the respondent on his or her identity may be as follows. As a person grows up, he or she is concerned that there is no job due to the age limit of the labor market. Thus, with age, he or she is more inclined to be an "employee" than "his own account worker". As the age grows, the physical and mental condition deteriorates, and the odds of his or her own business are more "employee" than "employees".

The economic variable of income has shown positive sign. The beta coefficient is 1.15 , which is not statistically significant. This means that the relative log of the "own account worker" increases with the increase in income compared to the "employee" reference category. In other words, the odds ratio greater than 1 is 3.158, which indicates that the relative risk ratio of a rupee's income growth is "3.158" for "own account workers" rather than "employees". This suggests that as incomes increase, people tend to "own their account" more than "employees". The impact of income on various employment conditions is vague. It can go in any direction. Often, when people have more income and resources, they are more inclined to build their own business, become a "their own account" rather than "employees."

In addition, with age, this person must face family and other social problems. So he / she was forced to do a job, the job was "employee" rather than "his own account". In Pakistan, especially in Multan, the people are poor, mostly engaged in agriculture-related majors, with low per capita income. In this case, a person as an employee rather than an "employer" because of age increases. Our results are well-matched with (Doltan and Makepeace, 1987; Krishnan, 1995; Blau and Khan, 2005; Glick and Shan, 2005 and Sen, 2000).

Marital status is again a demographic factor that affects the employment situation. The signs of

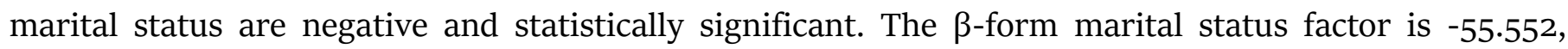
indicating that if a person is unmarried, the employer's logarithm may compare the number of employees by 55.552 units. The exponential regression coefficient of the marital status demonstrates the advantages of the reference group. In other words, the relative risk of using employee identities is higher than their account staff category. The reason for this relationship can be confirmed on the basis of the following. If a person is unmarried, usually in our society, he / she relies on other family members, but once he / she wants to get married or married, he / she should be breadwinner. In addition, the person does not have so much money to build his own business, so he / she is more inclined to get employee status in the labor market than his own account worker.

Gender variables are broken down into both men and women. There may be a positive or negative impact on the employment situation. If women or men are educated, they tend to be an employer rather than an employee, otherwise the opposite is true. The value of gender is positive and 
statistically significant. The value of $\beta$ is 2.357 , indicating that if a person is female; the employer's logarithm may be reduced by 2.357 units. The exponential regression of the same variables indicates the prevalence of the comparison group. In our example, the sex variable is positive, indicating that women will use their account workers as employees rather than employees because women are risky in a society and are dependent on nature, so they will never accept the employer identity of.

The next variable is home setups. This is a social variable that shows that the family can be a nuclear or a union. Family members are negative values, indicating that family members are the core; people use employee status rather than their own account staff. The value of $\beta$ is -0.159 , indicating that if the home setting is kernel-based, the number of employees with employees relative to their account may be reduced by 0.159 units. The $\operatorname{Exp}(\beta)$ of the family is 0.853 , which is less than 1 , showing the prevalence of the reference group. We can prove this result by the argument that a person lives in the core family system, and his or her living expenses may be low compared to the family system that they raise more people. So in the core family system, due to more financial space, a person can set up their own business to take the employer's position.

Another factor affecting the employment situation is the number of families. The number of families may have a positive and negative impact on the employment situation. This variable shows the dependency burden of a family, because people can judge the composition and size of a particular family population. Often, as the number of dependents increases, the number of dependents increases, and they have more tendencies to become employers than employees, because they do not need to feed people, and have more resources to carry out their careers and become employers. In our example, this variable has a negative sign, but it is politically insignificant. The value of a family account in the form of beta is -0.013, indicating that a person's increase in the number of households may increase the number of employers by 0.013 units relative to the employee's logarithm. The exponential regression coefficient $\operatorname{Exp}(\beta)$ of the number of households is greater than the relative risk ratio of the number of households representing the number of households between the employee and the employee is 0.987. The possible reason for the positive correlation between the number of family accounts and the number of family accounts is that as the number of families increases, as people increase their numbers, people have more money to build their own business and tend to be their own Account worker. Our results are validated by the following studies (Doltan and Makepeace, 1987; Krishnan, 1995; Blau and Khan, 2005 and Glick and Shan, 2005).

Finally, we also list the marital status and the interactive terminology of education in order to explore the employment situation when the interviewee is married and educated. The education coefficient of the respondents shows that the positive impact of the education level of the respondents on the employment situation and the number of marital status (unmarried) are negative for the employment situation, which is the exchange of EDU and MARS The role is positive, indicating that part of the impact of the interview on the "employer" employment situation is the average marital status of 18.16. This means that if a person is kept unmarried on average, his or her educational level increases, he will use the "own account worker" employment situation. Similarly, it can also be explained that if we take the average value of the respondents' education on the part of the marital status of the employment situation. The positive meaning is that if the person with educational value, the impact of marital status on the employment situation in the "own account" state is positive. The possible reason for this positive link in interactive terms is that unmarried educated people are more optimistic, realistic and impractical than married and uneducated people, so he obviously chooses to become an "employee" status of his own account Workers ". 


\section{Conclusions and Policy Implications}

This study has been designed to discover the determinants of employment status in the district Multan. It is primary data based study. We have collected data from 250 respondents. Three employment statuses have been set in accordance with the Pakistan Labor Force Survey (2015). The respondent has been selected with respect to sex, location etc. based on stratified random sampling. A very sophisticated econometric technique of Multinomial logistic regression has been utilize due to dependent categorical variable of employment status which is decompose into (i) Employee (ii) Employer and (iii) Own account worker. The base category of employment status is 'Employee' and the comparison categories are 'employer' and 'own account worker'. The explanatory variables are education of respondents, education of father, education of spouse, income of the respondents, age of respondents, household size, marital status, sex, family setups and the interaction term of marital status and education of respondents. Moreover an interaction term of marital status and education of respondent has been included to investigate the impact of education in the presence of education on the adoption of the employment status.

The main findings of this study exhibit that education of respondent and father, household size and family status are positively are related with employment status in comparison with employee status. While the education of spouse, income and sex are negatively related with employer status relative to the employee status. Moreover, the interaction term has appeared with positive sign.

If we discuss the determinants of employment status of own account worker in comparison with employee status, education of respondent, income and sex are positively related with the employment status of own account worker in comparison with employee status. So far as education of spouse, education of father, age of respondent, marital status and family status are concerned, these are negatively related with own account worker status of employment. This study is based on the socio economic demographic determinants of employment status. The most important employment status is employer which is according to spirit of Entrepreneurship. Our country is low developed country and facing many socio economic issues. Unemployment is the main issue for our country which has social and economic implications in all. The people of our country get education for getting jobs rather than the education for itself. People want to become employee rather than employer due to the job security, risk aversion and may other factors. It is necessary to persuade people towards the employment status for employer so that people can generate jobs and they would be able to reduce the unemployment in the country.

Keeping in view of the above points, it is necessary that people must adopt the employment status of employer. So, following policies may be suggested to enhance the adoption of employment status of employer.

i. Education level must be enhanced so that people would be more informative, risk lover and entrepreneurial.

ii. Household size has interesting implication with the employer status. A household with more family members has inducement to do their own work rather than being employer. So, household size must be enhanced if we want more employers in the country.

\section{References}

Bhaumik, S. K., Estrin, S., \& Meyer, K. E. (2007). Determinants of employment growth at MNEs: evidence from Egypt, India, South Africa and Vietnam. Comparative Economic Studies, 49(1), 6180. 
Blau, D. M. (1985). Self-employment and self-selection in developing country labor markets. Southern Economic Journal, 351-363.

Blau, F.D. and L. M. Kahn (2005). Changes in the Labour Supply Behaviour of Married Women: 19802000, Working Paper No. 11230, NBER (National Bureau of Economic Research) USA.

Dolton P. J., and Makespeace, G. H. (1987). The Labour Market, The Economic Journal, 56(4): 897-921.

Dunga, S. H., \& Sekatane, M. B. (2014). Determinants of employment status and its relationship to poverty in Bophelong Township. Mediterranean Journal of Social Sciences, 5(21), 215.

Ejaz, M. (2010). Determinants Of Female Labor Force Participation In Pakistan: An Instrumental Variable Approach (Doctoral dissertation, (C) Lahore School of Economics).

Faridi, M. Z., Chaudhry, I. S., \& Basit, A. B. (2009). An Analysis of the Determinants of Male Labor Force Participation and Employment Status in Pakistan: The Case of Bahawalpur District. Pakistan Journal of Social Sciences (PJSS), 29(2).

Faridi, M. Z., Chaudhry, I. S., \& Malik, M. S. (2011). Why Women are Self-Employed? Empirical Evidence from Pakistan. International Journal of Economics and Finance, 3(1), 198.

Faridi, M. Z., Chaudhry, I. S., Anwar, M., \& Majeed, A. (2010). The Determinants of Self-Employment in Pakistan: Evidence from Primary data Analysis. Journal of Political Studies, 17, 151.

Faridi, M. Z., Malik, S., \& Basit, A. B. (2009). Impact of Education on Female Labour Force Participation in Pakistan: Empirical Evidence from Primary Data Analysis. Pakistan Journal of Social Sciences (PJSS), 29(1).

Gillani, D. (2015). Female labour supply poverty, and informal sector employment a micro study. British Journal of Arts and Social Sciences, 28(1), 33-40.

Glick, P. and D. Shan (2005), Inter-temporal Female Labour force behavior in a developing country: what can we learn from a limited panel?” Labour Economics, 12(1): 23-45.

Hafeez, A., \& Ahmad, E. (2002). Factors determining the labour force participation decision of educated married women in a district of Punjab. Pakistan Economic and Social Review, 75-88.

Jayathunge, I. S. (2017, March). Determinants of Educated Women's Low Labour Force Participation in Sri Lanka. In Proceedings of International HR Conference (Vol. 3, No. 1).

Kaur, P. (2016). Factors Affecting Female Labor Force Participation in North East India. International Journal of Humanities and Social ScienceStudies, 3(2), 159.166.

Kaur, P., \& Kaur, G. (2012). Factors affecting female labour force participation in Punjab: An interdistrict analysis. Journal of Research in Peace Gender and Development, 2(4), 81-88.

Kazi, S., \& Havinga, I. C. (1987). Skill Formation, Employment and Earnings in the Urban Informal Sector [with Comments]. The Pakistan Development Review, 26(4), 711-719.

Kazi, S., Raza, B., \& Aziz, N. (1989). Women in the Informal Sector: Home-based Workers in Karachi [with Comments]. The Pakistan Development Review, 28(4), 777-788.

Kemal, A. R., \& Mahmood, Z. (1998). The Urban Informal Sector of Pakistan. Some Stylized Facts (No. 1998: 161). Pakistan Institute of Development Economics.

Killingworth, M. R., and J. J. Heckman (1986). Female labour Supply: A Survey Chapter 2. In Orley Ashenfelter and Richard Laynard (eds. )", Handbook of Labour Economics Vol. 1. New York: Elsevier Science Publishers. B.V. 103-204.

Kumara, A., \& Senanayaka, W. G. T. (2012). The Employment Status of the Elderly in Sri Lanka: Patterns and Determinants. University Library of Munich, Germany.

Kuznets, S. (1973) “Modern Economic Growth: Findings and Reflection”, American Economic Review 63.

Le, A. T. (2000). The determinants of immigrant self-employment in Australia. International Migration Review, 183-214.

Mincer, J. and S. Polachek (1974). Family Investment in Human Capital: Earnings of Women”, Journal of Political Economy, 82 (2) Part II: S76-S108. 
Narayanan, G. B. (2003). The Determinants of Employment in the Indian Textile Industry. Indira Gandhi Institute of Development Research Mumbai-400065 India.

Nikolova, V., \& Bargar, M. S. (2010). Determinants of self-employment in the United States. Undergraduate Economic Review, 6(1), 2.

Ohlsson, H., Broomé, P., \& Bevelander, P. (2010). The self-employment of immigrants and natives in Sweden: To what extent is it the'immigrant group'or the'labour market context'that affects the self-employment of individuals in Sweden? (No. 4976). Discussion paper series//Forschungsinstitut zur Zukunft der Arbeit.

Pietrobelli, C., Rabellotti, R., \& Aquilina, M. (2004). An empirical study of the determinants of self-employment in developing countries. Journal of International Development, 16(6), 803-820.

Raynor, J. L. (2007). Comparative civilian labor force statistics, 10 countries: a visual essay. Monthly Lab. Rev., 130, 32.

Saikia, P., \& Mazumder, R. (2015). An Empirical Analysis of the Determinants of Women Labour Force Participation among the Tiwa Tribe in Assam of North East India. International Journal of Social Science and humanities Research, 3(3).

Sarwar, F., \& Abbasi, A. S. (2013). An in-depth analysis of women's labor force participation in Pakistan. Middle-East Journal of Scientific Research, 15(2), 208-215.

Sen A. K. (1990), Gender and Cooperative Conflict”, in Irene Tinker (ed) Persisten Inequalities, Oxford University Press, New York.

Shaheen, R., Shabir, G., Faridi, M. Z., \& Yasmin, F. (2015). Determinants of Female Employment Status in Pakistan: A Case of Sahiwal District. Pakistan Journal of Commerce \& Social Sciences, 9(2).

Tripathi, S. (2016). Determinants of employment and unemployment situation in India with Special reference to North Eastern states of India. 